\title{
Serum Ferritin in Acute Leukaemia at Presentation and during Remission
}

\author{
D. H. PARRY, M. WORWOOD, A. JACOBS
}

British Medical fournal, 1975, 1, 245-247

\section{Summary}

In patients with acute myeloblastic leukaemia the mean serum ferritin concentration showed a twenty-five-fold increase compared with normal people, and in children with acute lymphoblastic leukaemia (A.L.L.) there was a thirteen-fold increase. The high concentration of circulating ferritin seemed to be related to increased synthesis by leukaemic cells. The return of serum concentrations to normal in A.L.L. patients after successful chemotherapy suggested that ferritin concentration may be a useful index of active disease and may help in prognosis.

\section{Introduction}

Serum ferritin concentration measured by immunoradiometric assay (Addison et al., 1972) correlates well with body iron stores in normal people and in patients with iron deficiency and iron overload (Jacobs et al., 1973; Walters et al., 1973). In leukaemia an increased serum ferritin concentration is common and does not seem to be related to iron stores (Jones et al., 1973; Worwood et al., 1974). In acute myeloblastic leukaemia the circulating leucocytes have a high ferritin content (Worwood et al., 1974), which seems to be due, at least in part, to increased ferritin synthesis (White et al., 1974). These findings suggested that serum ferritin concentration in A.M.L. might correlate with disease activity. The possibility of a similar abnormality in acute lymphoblastic leukaemia is suggested by the observation that normal lymphoid cells also contain ferritin (Summers et al., 1974).

We report here serial studies of serum ferritin concentration and other values in adults with A.M.L. and children with A.L.L. at different stages of their disease. The latter situation is of particular interest because, unlike adult leukaemia, prolonged survival and even cure may occur with modern chemotherapy regimens (Pinkel et al., 1971).

Department of Haematology, Welsh National School of Medicine, Cardiff CF4 4XN

D. H. PARRY, M.B., B.s., Lecturer

M. WORWOOD, PH.D., Lecturer

A. JACOBS, M.D., F.R.C.PATH., Professor

\section{Patients and Methods}

We examined blood samples taken as part of another study from 27 normal children aged 1 year. This group was not comparable in age with the leukaemic children but was used to confirm the normal range (Siimes et al., 1974), when it was found that serum ferritin concentration remains relatively constant from 6 months to 15 years of age. Haematological values are shown in table $I$ and serum ferritin concentration in table III.

Eleven adults with A.M.L., aged 18-62 years, were examined at presentation and ten of these after they had achieved a complete clinical, blood, and bone marrow remission.

Thirty-nine children with untreated A.L.L., ranging in age from 5 months to 11 years, were investigated. Haematological values are shown in table I. Another 38 children with A.L.L., aged 5 months to 17 years, were also investigated. All were in complete remission but they were still receiving maintenance therapy. Not all the children had been in continuous complete remission since diagnosis as some had had haematological or central nervous system relapses. A further 31 children with A.L.L., aged 3-15 years, who had stopped all chemotherapy and were in complete remission were also studied. In both these groups criteria for remission were those used in the Medical, Research Council's therapeutic trials (Medical Research Council 1963).

Serum iron concentration and total binding capacity were measured by the method of Young and Hicks (1965), and serum and white cell ferritin concentrations using the immunoradiometric assay of Addison et al. (1972) and the separation techniques previously described (Worwood et al., 1974).

In patients with A.M.L., all of whom were from Cardiff, serum aspartate aminotransferase (SGOT) activity was measured as an index of liver cell damage, while in patients with A.L.L., most of whom came from centres involved in the UKALL trials, serum alanine aminotransferase (SGPT) activity was routinely measured.

\section{Results}

Serum and leucocyte ferritin concentrations in patients with A.M.L. are shown in table II together with previously reported normal values. Remission samples were all taken just before a course of chemotherapy-that is, about one month after the previous course. Increased serum and white cell ferritin concentrations were found in untreated patients. In remission all patients had even higher serum ferritin concentrations, the mean increase being $289 \mu \mathrm{g} / 1(23 \%)$ over the initial mean value $(P<0.001)$. Leucocyte ferritin concentrations decreased in all but one patient during remission and the mean difference of $64 \mathrm{fg} /$ cell $(71 \%)$ for the whole group was significant $(P<0.05)$, but only in five individual cases did the ferritin concentration fall within the normal range. The increase in serum ferritin concentration was not correlated with the amount of blood transfused or the degree of liver damage as assessed by serum

TABLE I-Haematological Values (Means \pm S.E. and Ranges) in Normal Children, Untreated Children with A.L.L., and Untreated Adults with A.M.L.

\begin{tabular}{|c|c|c|c|c|c|}
\hline & $\begin{array}{c}\text { Haemoglobin } \\
\mathbf{g} / \mathrm{dl})\end{array}$ & $\begin{array}{l}\text { W.B.C. } \\
\left(\times 10^{\circ} / 1\right) \\
\end{array}$ & $\begin{array}{l}\text { Platelets } \\
\left(\times 10^{\circ} / 1\right) \\
\end{array}$ & $\begin{array}{c}\text { Serum Iron } \\
(\mu \mathrm{mol} / \mathrm{l})\end{array}$ & $\begin{array}{l}\text { T.I.B.C. } \\
(\mu \mathrm{mol} / \mathrm{l})\end{array}$ \\
\hline $\begin{array}{l}\text { Normal children } \\
\text { Untreated children with A.L.L. } \\
\text { Untreated adults with A.M.L. }\end{array}$ & $\begin{array}{l}12 \cdot 1 \pm 0 \cdot 14 \\
(11 \cdot 0-13 \cdot 8) \\
6 \cdot 5 \pm 0 \cdot 16 \\
(2 \cdot 7-11 \cdot 3) \\
8 \cdot 6 \pm 0 \cdot 8 \\
(4 \cdot 3-13 \cdot 5)\end{array}$ & $\begin{array}{l}19 \cdot 5 \pm 4 \cdot 9 \\
(0 \cdot 5-154) \\
23 \cdot 7 \pm 8 \\
(1 \cdot 8-43 \cdot 4)\end{array}$ & $\begin{array}{c}65 \cdot 8 \pm 11 \cdot 6 \\
(1-325) \\
49 \pm 14 \\
(2-140)\end{array}$ & $\begin{array}{l}12 \cdot 35 \pm 1 \cdot 1 \\
(3 \cdot 94-26 \cdot 85) \\
21 \cdot 84 \pm 2 \cdot 15 \\
(5 \cdot 37-65 \cdot 16) \\
40 \cdot 28 \pm 4 \cdot 12 \\
(22 \cdot 20-66 \cdot 56)\end{array}$ & $\begin{array}{c}98 \cdot 09 \pm 9 \cdot 13 \\
(63.55-187.95) \\
94 \cdot 15 \pm 4 \cdot 12 \\
(49 \cdot 23-134 \cdot 25) \\
57 \cdot 82 \pm 2 \cdot 51 \\
(43.86-75 \cdot 18)\end{array}$ \\
\hline
\end{tabular}


TABLE II-Serum and Leucocyte Ferritin Concentrations (Means \pm S.E. and Ranges) in Normal Adults and Patients with A.M.L. (Mean \pm S.E. and Range)

\begin{tabular}{|c|c|c|c|}
\hline & $\begin{array}{c}\text { No. of } \\
\text { Subjects }\end{array}$ & $\begin{array}{c}\text { Serum Ferritin } \\
\text { Concentration } \\
(\mu \mathrm{g} / \mathrm{l})\end{array}$ & $\begin{array}{l}\text { Leucocyte Ferritin } \\
\text { Concentration } \\
\text { (fg/cell) }\end{array}$ \\
\hline Normal men & 75 & $\begin{array}{l}69 \pm 5 \\
(6-186)^{*}\end{array}$ & $\begin{array}{l}6 \cdot 9 \pm 2 \cdot 7 \\
(4 \cdot 3-12 \cdot 0)+\end{array}$ \\
\hline Normal women & 44 & $\begin{array}{c}35 \pm 5 \\
(3-162)^{*}\end{array}$ & $\begin{array}{l}7 \cdot 2 \pm 4 \cdot 8 \\
(1 \cdot 3-16 \cdot 1) \dagger\end{array}$ \\
\hline $\begin{array}{l}\text { Patients with A.M.L.: } \\
\text { At presentation }\end{array}$ & 11 & $1278 \pm 367$ & $89.6 \pm 26$ \\
\hline In remission & 10 & $\begin{array}{l}1567 \pm 331 \\
(764-4389)\end{array}$ & $\begin{array}{c}25 \cdot 7 \cdot \pm 10 \cdot 8 \\
(3 \cdot 5-97)\end{array}$ \\
\hline
\end{tabular}

*Data from Jacobs et al. (1972).
+Data from Worwood et al. (1974).

transaminase levels. The mean SGOT ( \pm S.E.) activity in these patients was lower in remission (mean $26 \pm 15 \mathrm{U}$ ) than at presentation (mean $64 \pm 79 \mathrm{U}$ ), the normal range being 5-35 $\mathrm{U}$. There was no correlation between SGOT activity at presentation and the initial serum ferritin concentration.

In normal children serum ferritin concentrations were between 3 and $58 \mu \mathrm{g} / \mathrm{l}$, significantly lower than the values found in adults and agreeing well with the values reported by Siimes et al. (1974).

In the patients with untreated A.L.L. the mean serum ferritin concentration was $301 \pm 44 \mu \mathrm{g} / \mathrm{l}$ (table III). There was no correlation between the serum ferritin concentration and the total white cell count, the peripheral blood blast count, haemoglobin concentration, or the initial SGPT level.

In those with A.L.L. in remission with maintenance therapy the mean serum ferritin concentration was higher than in untreated cases. No correlation was found between the serum ferritin concentration and the number of units of blood administered.

TABLE III-Serum Ferritin Concentrations in Normal Children and Patients with A.L.L.

\begin{tabular}{|c|c|c|c|}
\hline & \multirow{2}{*}{$\begin{array}{c}\text { No. of } \\
\text { Subjects }\end{array}$} & \multicolumn{2}{|c|}{ Serum Ferritin Concentration $(\mu \mathrm{g} / \mathrm{l})$} \\
\hline & & Mean \pm S.E. & Range \\
\hline $\begin{array}{l}\text { Normal children } \\
\text { Patients with untreated } \\
\text { A.L.L. } \\
\text { A.L.L. patients in remission } \\
\text { with chemotherapy } \\
\text { A.L.L. pa ients in remission } \\
\text { with chemotherapy } \\
\text { stopped }\end{array}$ & $\begin{array}{l}27 \\
39 \\
38 \\
31\end{array}$ & $\begin{array}{r}23 \pm \quad 3 \\
301 \pm 44 \\
912 \pm 149 \\
50 \pm 8\end{array}$ & $\begin{array}{c}3-58 \\
43-1137 \\
170-5115 \\
12-206\end{array}$ \\
\hline
\end{tabular}

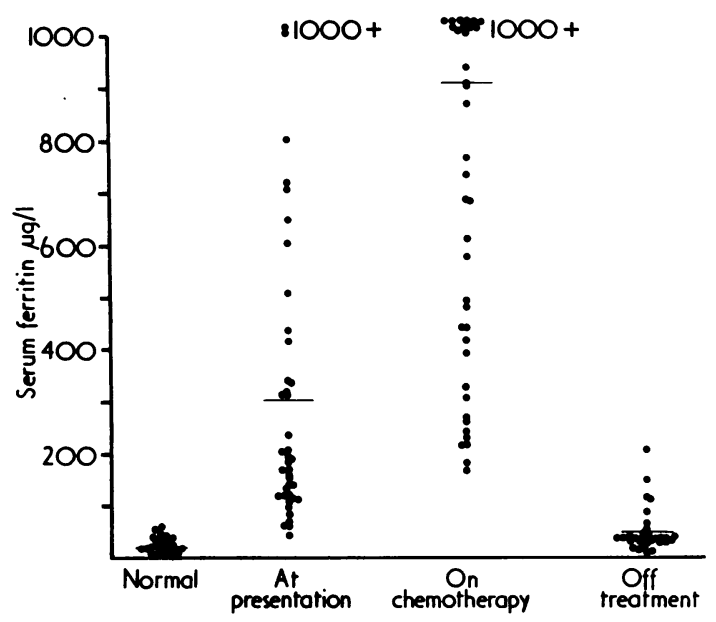

Serum ferritin concentrations in normal children and patients with A.L.L. Horizontal lines indicate mean values.
In those patients in remission after chemotherapy was stopped serum ferritin concentrations were much lower than in other patients with A.L.L. (mean $50 \pm 8 \mu \mathrm{g} / \mathrm{l}$ (table III)). Most values fell within the normal range (see fig.), but the mean value differed significantly from that of the group of normal children $(P<0.005)$. There was no correlation between serum ferritin concentration and the number of units of blood transfused or the transaminase activity.

\section{Discussion}

The increase in serum ferritin concentration that occurs in A.M.L. has been reported (Jones et al., 1973), and this increase is associated with high concentrations of the protein in leukaemic cells (Worwood et al., 1974). Incubation of peripheral blood leucocytes from such patients in a medium containing ${ }^{14} \mathrm{C}$ leucine indicates increased incorporation into ferritin (White et al., 1974). Our results confirm the raised serum and leucocyte ferritin concentrations in A.M.L. In 10 patients who achieved a full clinical and haematological remission the leucocyte ferritin concentration fell associated with a return of the peripheral blood picture to normal, though normal concentrations were not obtained in most cases. Serum concentrations were significantly higher during remission than at presentation.

In untreated patients with A.L.L. the mean serum ferritin concentration was about 15 times higher than normal for that age group, being normal in only one case (see fig.). During chemotherapy circulating ferritin levels were higher than during the pretreatment period, a similar phenomenon to that seen in A.M.L. There was no correlation between ferritin concentration and length of remission in patients still on chemotherapy. Sera were examined from 31 children with A.L.L. who had reached the end of their treatment regimen and were receiving no chemotherapy. All were in remission and most had been in the M.R.C. trial UKALL I. All except six patients had a serum ferritin concentration within the normal range though the mean concentration in this group as a whole was significantly higher than normal. No leucocytes were available for study in this group.

The increased capacity for ferritin synthesis shown by myelogenous cells from patients with A.M.L. (White et al., 1974) suggests that these cells themselves are the source of the increased amount of circulating protein. Preliminary evidence suggests that a similar increase of ferritin synthesis occurs in A.L.L. (Parry, 1974). In both conditions the increase in cirulating ferritin during chemotherapy could be due to an increased release from damaged leukaemic cells. Possibly also chemotherapy damages other ferritin-containing cells but the lack of correlation with serum transamine activity makes it unlikely that liver parenchymal cells are an important source. Similarly, the lack of correlation between raised serum ferritin concentration and the amount of blood transfused, in contrast to aplastic anaemia (Jacobs et al., 1972), makes it unlikely that this originates from increased stores. In patients not receiving chemotherapy an increase in serum ferritin concentration may be related to the leukaemic cell mass. Unfortunately patients with A.M.L. cannot be maintained without chemotherapy at present nor is it likely that the leukaemic cell mass is eliminated by current regimens. In A.L.L., however, both these conditions may be achieved. The low serum ferritin concentrations found in long-term survivors of A.L L suggest that ferritin concentration may be a useful index for the prediction of relapse and as a prognostic sign. With improved therapeutic regimens the same may eventually be true for A.M.L. patients.

This work was supported by a grant from the Leukaemia Research Fund. We are grateful to the many haematologists who helped by sending us specimens and information about their patients, in particular Professor O. P. Gray, Professor R. M. Hardisty, Dr. H. E. M. Kay, Dr. P. Morris Jones, Dr. J. Stuart, Dr. E. Thompson, and Dr. J. A. Whittaker. 


\section{References}

Addison, G. M., et al. (1972). Fournal of Clinical Pathology, 25, 326 Jacobs, A., et al. (1972). British Medical fournal, 4, 206.

Jones, P. A. E., et al. (1973). British fournal of Cancer, 27, 212.

Parry, D. H. (1974). Unpublished data.

Pinkel, D. (1971). Fournal of the American Medical Association, 216, 648.

Medical Research Council (1963). British Medical fournal, 1, 7.
Siimes, M. A., Addiego, J. E., and Dallman, P. R. (1974). Blood, 43, 581. Summers, M., Worwood, M., and Jacobs, A. (1974). British fournal of Haematology, 28, 19.

Walters, G. O., Miller, F. M., and Worwood, M. (1973). Fournal of Clinical Pathology, 26, 770 .

White, G. P., et al. (1974). Nature, 250, 584.

Worwood, M., et al. (1974). British fournal of Haematology, 28, 27.

Young, D. S., and Hicks, J. M. (1965). Fournal of Clinical Pathology, 18, 98

\title{
Incidence of Early Post-operative Iliofemoral Thrombosis
}

\author{
J. P. BOLTON, V. J. HOFFMAN
}

British Medical fournal, 1975, 1, 247-249

\section{Summary}

The Doppler ultrasound probe was used to study 138 patients after major surgery to assess the incidence of iliofemoral thrombosis in the early postoperative period. The patients were simultaneously studied with the ${ }^{125}$ Ifibrinogen uptake test. The accuracy of the ultrasonic technique was assessed concurrently by comparing its results with those of ascending phlebography in a separate group of patients.

The ultrasound probe detected thrombus proximal to the calf but was inaccurate in locating its exact site. Of the 138 patients studied postoperatively 28 developed calf vein thrombosis detected isotopically, but there was no evidence of iliofemoral thrombosis in any patient. Thus, spontaneous iliofemoral thrombosis in the early postoperative period is rare.

\section{Introduction}

The technique of using human fibrinogen labelled with radioactive iodine to detect postoperative deep vein thrombosis (Hobbs and Davis, 1960; Atkins and Hawkins, 1965) has led to a greater understanding of the incidence and natural history of the condition (Flanc et al., 1968; Kakkar et al., 1969). The technique reliably detects thrombosis in the calf and popliteal veins (Negus et al., 1968). It is not so accurate in diagnosing thrombus in the proximal femoral vein, however, and cannot detect it in the iliac veins, and it is from these areas that dangerous pulmonary emboli arise. It has been suggested (Sevitt, 1962; Mavor and Galloway, 1969; Mavor et al., 1972) that such proximal thrombi do not necessarily arise in association with and as a result of distal calf vein thrombosis, and if this is so then ${ }^{125} \mathrm{I}$-fibrinogen studies do not detect the patients most at risk of developing a dangerous pulmonary embolus.

This study was done to determine the incidence of iliofemoral thrombosis in the early postoperative period by studying patients simultaneously with the Doppler ultrasound probe for the iliofemoral segment and the ${ }^{125}$ I-fibrinogen uptake test for the calf and popliteal region (study 2). At the same time we assessed the accuracy of the Doppler ultrasound probe by comparing its findings with those of ascending phlebography in patients presenting with signs and symptoms suggestive of a pulmonary emboius or a deep vein thrombosis (study 1 ).

\footnotetext{
Department of Surgical Studies, Middlesex Hospital, London
W1P 7PN

J. P. BOLTON, M.B., F.R.C.S., Surgical Registrar

V. J. HOFFMAN, M.B., F.R.C.s., Surgical Registra
}

\section{Technique}

The ultrasound machine used was a Sonicaid D205 with a $2-\mathrm{MHz}$ output. The technique of using the machine was based on that described by Evans and Cockett (1969). The method relies on detecting augmentation or " $A$ " waves over the major veins of the lower limb and pelvis when the limb is compressed at a lower level. The transducer is placed successively over the superficial femoral, common femoral, and external iliac veins and the inferior vena cava two inches $(5 \mathrm{~cm})$ above and to the right of the umbilicus, and $A$ waves are detected after compression of the limb at varying points distally. By defining the highest point in the limb at which the $\mathrm{A}$ wave is absent or abnormal on compression it is theoretically possible to determine not only the presence of but also the upper limit of a thrombus. The method cannot be expected to localize the exact extent of thrombus in the calf and popliteal region. For instance, if with the transducer over the superficial femoral vein compression of the calf does not produce an A wave but compression of the lower thigh produces a normal one there may be either extensive thrombus confined to the calf or a thrombus in the popliteal vein at the level of the knee joint.

In the postoperative patients we found it impossible to detect A waves in the inferior vena cava because abdominal wounds and associated drains and dressings prevented satisfactory positioning of the transducer. The patency of the iliac veins was, therefore, assessed by studying spontaneous or " $S$ " waves (Sigel, 1968) at the level of the external iliac veins. $S$ waves are produced by the alteration in flow in the major veins caused by changes in the intrathoracic pressure in inspiration and expiration. The $2-\mathrm{MHz}$ machine allows the flow in the external iliac veins to be detected easily, and we found that the $S$ waves are heard better over this vessel than over the common femoral vein. If the patient takes deep breaths the $S$ waves are accentuated. If $S$ waves are detected in the external iliac veins this implies that the flow in these veins is being directly influenced by changes in the intrathoracic pressure and, therefore, there can be no major obstruction in the inferior vena cava or the common iliac vein on the same side.

We tried to localize the upper limit of the thrombus to one of three segments; iliac, femoral, or popliteal/calf. The detection of thrombus below the external iliac vein was based on A wave abnormalities and above the external iliac vein on the alteration in $S$ waves heard at that level.

In the postoperative patients potassium iodide $100-150 \mathrm{mg}$ was given by mouth or intravenously the day before operation and continued daily for two weeks. Human fibrinogen from a pool of screened donors was iodinated at the Radiochemical Centre, Amersham, and $100 \mu \mathrm{Ci}$ was given within three hours of the completion of operation. The patients' legs were studied with the Pitman isotope localization monitor one, two, four, and six days after operation and for longer if a deep vein thrombosis was present. The method of counting and the criteria for diagnosis were as described by Negus et al. (1968) except that a persistent $20 \%$ difference between adjacent points or an 